good enough 



\title{
good enough
}

\author{
The Tolerance for Mediocrity \\ in Nature and Society
}

D A N I E L S. M I L O

\section{III \\ III}

Harvard University Press

Cambridge, Massachusetts

London, England

2019 
Copyright (C) 2019 by the President and Fellows of Harvard College All rights reserved

Printed in the United States of America

First printing

Cover image: Giraffe/Private Collection/Bridgeman Images

Cover design: Jill Breitbarth

$$
\begin{gathered}
9780674240056 \text { (EPUB) } \\
9780674240063 \text { (MOBI) } \\
9780674240049 \text { (PDF) }
\end{gathered}
$$

The Library of Congress has cataloged the printed edition as follows:

Names: Milo, Daniel S. (Daniel Shabetaï), author.

Title: Good enough : the tolerance for mediocrity in nature and society / Daniel S. Milo.

Description: Cambridge, Massachusetts : Harvard University Press, 2019. |

Includes bibliographical references and index.

Identifiers: LCCN 2018052620 | ISBN 9780674504622 (alk. paper)

Subjects: LCSH: Evolution (Biology) | Natural selection. | Social evolution. | Imperfection.

Classification: LCC QH366.2 .M555 2019 | DDC 576.8—dc23

LC record available at https://lccn.loc.gov/2018052620 
In memory of my beloved,

Naomi Aviv Milo,

who knew 
